\title{
DEVELOPMENT OF THE MODEL OF DECISION SUPPORT FOR ALTERNATIVE CHOICE IN THE TRANSPORTATION TRANSIT SYSTEM
}

\author{
Igor Kabashkin ${ }^{1}$, Jelena Lučina ${ }^{2}$ \\ Transport and Telecommunication Institute \\ Lomonosova 1, Riga, LV-1019, Latvia \\ IPhone:+37129215392.E-mail:kiv@tsi.lv \\ 2Phone: +371 29584606.E-mail: hmv@inbox.lv
}

The decision support system is one of the instruments for choosing the most effective decision for cargo owner in constant fluctuated business environment. The objective of this Paper is to suggest the multiple-criteria approach for evaluation and choice the alternatives of cargo transportation in the large scale transportation transit system for the decision makers - cargo owners. The large scale transportation transit system is presented by directed finite graph. Each of 57 alternatives is represented by the set of key performance indicators Kvi and set of parameters Paj. There has been developed a two-level hierarchy system of criteria with ranging expert evaluations based on Analytic Hierarchy Process Method. The best alternatives were suggested according to this method.

Keywords: Transport model, transit, decision support, Baltic Sea Region

\section{Global logistics trends and freight transport development}

International business has been undergoing a period of rapid transformation. Researchers at the McKinsey Global Institute (McKinsey Global Institute, 2012) calculated the economic centre of gravity of the world by using Gross National Product (GDP) as a measure of the mass or weight of a country and using the world map as a physical object (Figure 1).

Based on the calculations, the centre of gravity in 1950 was in the Atlantic Ocean. Today the centre of gravity is over southern Russia and moving eastward, as shown in the map at figure 1. As a result of shift of economic mass, supply chain configurations are becoming increasingly volatile and the shift in the global economic centre of gravity to emerging regions may see reduced growth on traditional trade routes. Such restructuring is contributing to economic growth, better allocation of resources and more freedom of choice for consumers, as well as increased competition. In order to be internationally competitive, businesses are organising strategic worldwide networks that can deliver an efficient and high-quality response to demand from any segment of the world market. The efficient and integrated organisation of such activities is often referred to as global logistics and it has become the core of global competitive power. Business will need extensive market intelligence for using the opportunities that arise from this change of economic centre of gravity.

Global logistics networks serve as a circulatory system for the corresponding global value-adding chain where various components in the logistics network serve different functions in an organisationally unified manner. Therefore, in order to establish a region as a key component in global logistics networks, it is necessary to create a vision of how to position the region strategically within the context of the overall global logistics networks. 


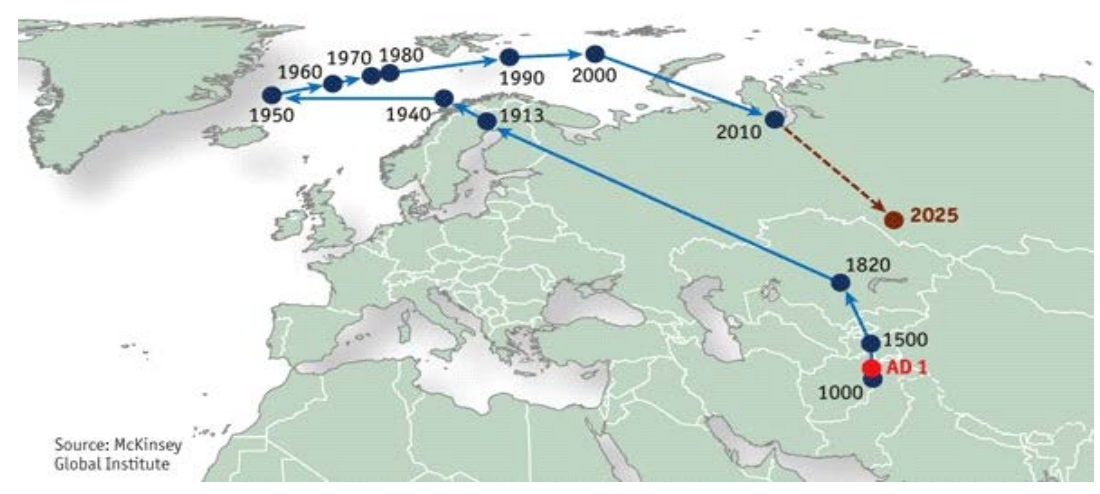

Figure 1. Evaluation of the earth's economic centre of gravity

Development pattern of the particular sectors within the EU transport system is quite unbalanced which is preconditioned by the following factors: first of all, the extent of the particular countries involvement into the work of the transport industry varies from country to country; secondly, it is influenced substantially by the pattern of the EU financial packages allocation. Nowadays one of the top priorities of the EU transport policy is the expansion of the Trans-European networks (the possibility is envisaged even to stretch them outside the EU borders), as well as building up the global transport corridors in cooperation with other countries.

Any strategy adopted for the purposes of the transport system development marking worth since it contains two split-level components. One of these components is of a global character: today the appropriate infrastructure including transport must be ensured to guarantee a successful development of a given region. This assumption quite logically leads us to the next level - the EU specifically formulated practical proposals and problem-solving strategies. The same two-level approach can be used to describe the EU transport policy. However, when stipulating the EU transport policy, one has to take into account a major impact it confronts due to the influence of political and economic factors.

The Baltic region is remarkable for its economically advantageous geographical position within the Eurasian transport system, connecting Russia with the biggest world markets of the Central and Eastern Europe as well as with the Baltic States and the CIS States and China. In the situation where a large increase in trade and freight transport volumes in the Baltic Sea Region (BSR) is expected and in which the BSR is facing a major economic restructuring, efforts to additional study of more integrated and sustainable transport and communication links within the BSR are needed.

The volatility and uncertainties of today's economic environment and expanding global supply chains require coordinated efforts to optimise network configurations and inventories to synchronise global supply and demand. At the same time, new business models are emerging with shift to customerdriven supply chains. Reconfiguring supply chains around customers has led to the necessity for more flexible and adaptive formation system of transport and logistics links. In this situation decision support system (DSS) is one of the instruments for choosing the most effective decision for a customer in constant fluctuated business environment.

There are seven typical steps in the process of multi-criteria decision making (Sinha, 2007):

- to identify transportation alternatives;

- to establish performance criteria;

- to establish relative importance of performance criteria;

- to establish commensurate scale for measuring levels of each criteria;

- Using the established scale, quantify level (impact) of each criterion for each alternative action;

- to establish the combined impact of the different criteria for each alternative;

- to determine the most satisfying alternative.

The first two tasks mentioned above are the subject of the current investigation. 


\section{Identification of transportation alternative. Case study for the route "China - Russia"}

Containerization greatly reduced the expense of international trade and increased its speed, especially of consumer goods and commodities. Today approximately $90 \%$ of non-bulk cargo worldwide is moved by containers stacked on transport ships (Mikulko, 2013).

The increasing use of containers in transport has increased the share of intermodal transport chains, which contain several modes of transport. Cost-efficient railway or sea transport is used on the main routes of intermodal transport, while flexible road transport is used in collection and distribution activities.

Therefore the main transport corridors connecting China and Russia for containerised cargoes are:

1. Southeast China -all-water route via Suez Canal to Baltic Sea;

2. Southeast China -all-water route via Suez Canal to Black Sea;

3. International Transport Corridor "Trans-Siberian" (or "East-West", the backbone of which is Trans-Siberian Railway) with different connections to rail/sea/road and delivery network at both ends;

4. West Europe-West China (through Kazakhstan territory) - rail and road connections.

The main competition is taking place between the two all-water routes and "Trans-Siberian" transport corridor. The ocean route through the Suez Canal is the most important trade route between the Far East, Southeast Asia and Europe and Russia. Large and global companies have developed an efficient logistics system which consists of a collection and delivery network at ends, terminals and large vessels for which some type of vessels can transport till $18000 \mathrm{TEU}$ at a time.

Containerized cargoes are transported via shipping lines and operated on a regular basis. There are three main shipping companies (and brand leaders) in the container industry that provide services worldwide in the industry. They have about 39.65\% market share together. These are APM-Maersk, Mediterranean Shipping Company and CMA-CGM Group. These three shipping lines are the main service providers for cargoes transhipped through the Baltic ports (Midoro, 2005). Short sea connections are based on these three main service providers:

1. Loading place in China-Main China port-Hamburg-Riga-Custom clearance place-Unloading place

2. Loading place in China-Main China port-Hamburg-Klaipeda-Custom clearance placeUnloading place

3. Loading place in China-Main China port-Hamburg-Tallinn-Custom clearance placeUnloading place

4. Loading place in China-Main China port-Hamburg-HaminaKotka-Custom clearance placeUnloading place

5. Loading place in China-Main China port-Bremerhaven-St. Petersburg-Unloading place

6. Loading place in China-Main China port-Gdansk-Riga-Custom clearance place-Unloading place

7. Loading place in China-Main China port-Gdansk-Klaipeda-Custom clearance placeUnloading place

8. Loading place in China-Main China port-Gdansk-Tallinn-Custom clearance place-Unloading place

9. Loading place in China-Main China port-Gdansk-HaminaKotka-Custom clearance placeUnloading place

10. Loading place in China-Main China port-Gdansk-Ust Luga-Unloading place

11. Loading place in China-Main China port-Zeebrugge-Ust Luga- Unloading place

12. Loading place in China-Main China port-Rotterdam- St. Petersburg-Unloading place

13. Loading place in China-Main China port-Antwerp-Riga Custom clearance place-Unloading place

14. Loading place in China-Main China port-Antwerp-Klaipeda Custom clearance placeUnloading place 
15. Loading place in China-Main China port-Antwerp-Tallinn Custom clearance placeUnloading place

16. Loading place in China-Main China port-Antwerp-HaminaKotka-Custom clearance placeUnloading place

17. Loading place in China-Main China port-Antwerp-St. Petersburg-Unloading place

18. Loading place in China-Main China port-Novorossiysk-Railway station in Russia-Unloading place

19. Loading place in China-Main China port-Novorossiysk-Unloading place

20. Loading place in China-Main China port-Odessa-Custom clearance place-Unloading place

21. Loading place in China-Main China port-Odessa-Railway station in Russia-Unloading place

22. Loading place in China-Main China port- Vladivostok/Nahodka/Vostochny-Railway station in Russia-Unloading place

23. Loading place in China-Main China port-Railway station for train departure in China- SuheBator (MN) - Naushki (RU) border-Railway station in Russia-Unloading place

24. Loading place in China-Main China port-Railway station for train departure in ChinaManzhouli (CN) - Zabaikalsk (RU) border-Railway station in Russia-Unloading place

25. Loading place in China-Main China port-Railway station for train departure in ChinaAlashankou (CN) - Dostyk (KZ) border-Railway station in Russia-Unloading place

26. All mentioned possibilities could be started by rail or road transportation of cargo to the China main port (50 above mentioned transportation chains).

27. Loading place in China- Railway station for train departure in China- Suhe-Bator (MN) Naushki (RU) border-Railway station in Russia-Unloading place

28. Loading place in China-Railway station for train departure in China- Manzhouli (CN) Zabaikalsk (RU) border-Railway station in Russia-Unloading place

29. Loading place in China-Railway station for train departure in China- Alashankou (CN) Dostyk (KZ) border-Railway station in Russia-Unloading place

30. Three mentioned possibilities could be started by rail or road transportation of cargo to the Railway station for train departure in China (6 above mentioned transportation chains).

31. Loading place in China - Horgos $(\mathrm{CN})$ - Korgas $(\mathrm{KZ})$ border-Custom clearance place in Russia-Unloading place (by road)

There could be several alternatives found for cargo delivery, determined by different routes and modes which form the vector space of a family of alternative transit vector routes. There are 57 alternatives of cargo transportation in the large scale transportation transit system in total which can be presented by graph shown at figure 2. All 57 routes and divided into seven clusters:

1. $(1-3)+(6-8)+(13-15)-1$ st cluster. Transportation through Baltic ports (Riga, Klaipeda, Tallinn);

2. $(4+9+16)-2$ nd cluster. Transportation through Finland (HaminaKotka port);

3. $(5+12+17+18+19)-3$ rd cluster. Transportation through St. Petersburg port, Ust Luga port;

4. (18-21) - 4th cluster. Transportation through Novorossiysk, Odessa ports;

5. $22-5$ th cluster. Transportation through Vladivostok/Nahodka/Vostochny ports;

6. (23-28) - 6th cluster. Direct railway solutions (Trans-Siberian Railway and West Europe-West China corridor);

7. $29-7$ th cluster. Transportation by truck (West Europe-West China corridor). 


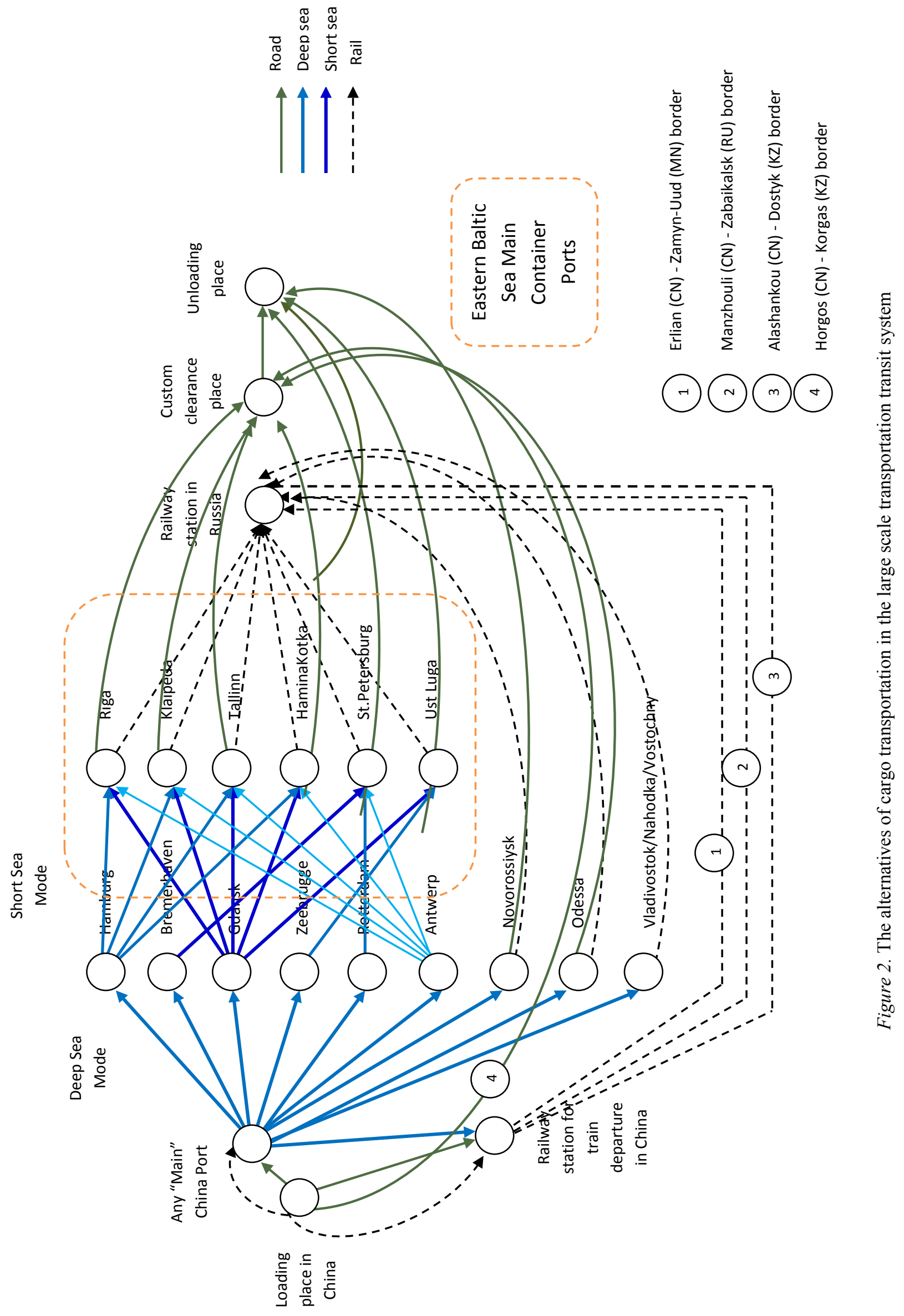


The large scale transportation transit system is presented by directed finite graph which is an ordered pair $\mathrm{D}=(\mathrm{V}, \mathrm{A})$ where $\mathrm{V}$ is set of finite vertices (railway stations, ports, border points and logistics centres) and A is set of finite arcs (transport lines between ports and/or logistics centres). The vertices are grouped in clusters. In each cluster only one vertex can be used as alternative for transit routes. Each vertex $\mathrm{Vi}(\mathrm{V}=\{\mathrm{Vi}\}, \mathrm{i}=1, \ldots \mathrm{n})$ is characterized by an individual set of key performance indicators $K_{v i}$ and each arc aj $\left(A=\left\{a_{j}\right\}, j=1, \ldots m\right)$ is characterized by an individual set of parameters $P_{a j}$. The set of key performance indicators $K_{v i}$ and set of parameters $P_{a j}$ are described further. solving.

If all characteristics of the graph were known the research would come down to the standard task

The standard System of KPI (Key Performance Indicators) of ports and other Logistics objects currently used in the Baltic States came down to the very simple provide an incomplete picture of competitiveness. These KPIs are primarily describing the gross level of logistic object activity (e.g. total TEU or total tonnage). But traffic volumes often present a distorted picture: they are not always accurate (e.g., transhipment ports double count containers, once when unloaded and then when reloaded), container volumes give equal weight to empty and loaded boxes, cargo tonnages often include container tare weight, they do not distinguish between low-value/high-volume bulk cargoes and high-value unitized cargoes, and they are affected by a number of exogenous factors which makes it difficult to establish solid correlations with a logistic object's competitiveness (The World Bank, 2013). It is often sought to make transportation decision on the basis of wider range of performance criteria that reflect the concerns of all key stakeholders, i.e. agency goals, perspectives of facility users, concerns of society as a whole, environmental impact from transportation and others (Maciulis, 2009; Kopytov, 2010). But in reality such criteria are not decisive for the cargo owners.

That's why the set of key performance indicators $K_{v i}$ and set of parameters $P_{a j}$ should be determined to suggest further the multiple-criteria approach for evaluation and choice the alternatives of cargo transportation in the large scale transportation transit system with special attention to Baltic Sea Region.

\section{Performance criteria for transportation decision making}

There are a lot of major issues in business decision making in the international container transportation industry and cargo owners determine the mode by which they will have their freight transported, considering mainly their corporate, personal priorities. One of the general approaches for taxonomy of cargo owner's preferences was proposed in (Kabashkin, 2003). The framework D for decision making sets out the factors influencing the transit sector from users' point of view in the order of their priority:

$$
D=\cap_{k=1}^{5} A_{k}, A_{k}=\left\{a_{k i}\right\}, i=\overline{1, m_{k}},
$$

where $A_{k}$ - factor of influence with $m_{k}$ parameters:

$A_{1}$ - geographical plane,

$A_{2}$ - economical plane,

$A_{3-\text { institutional/political plane, }}$

$A_{4}$ - infrastructure plane,

$A_{5}$ - technology plane.

The choice of parameters at higher levels $A_{k+1}, k=\overline{1,4}$ become feasible when lower level $A_{k}$ is achieved.

But $A_{3}=\left\{\frac{1}{0}, " 1 "-\right.$ if institutional and political situation in transit area is acceptable for users, " 0 " - otherwise.

In this case the analyse could be minimized by making decision support system taking into account the infrastructural, technological, economical, geographical factors and excepting the political.

Taxonomy of KPI Kvi for this model can be described by set of parameters shown at the figure 3 with suggested quantitative metrics for both - quantitative and qualitative KPIs. 


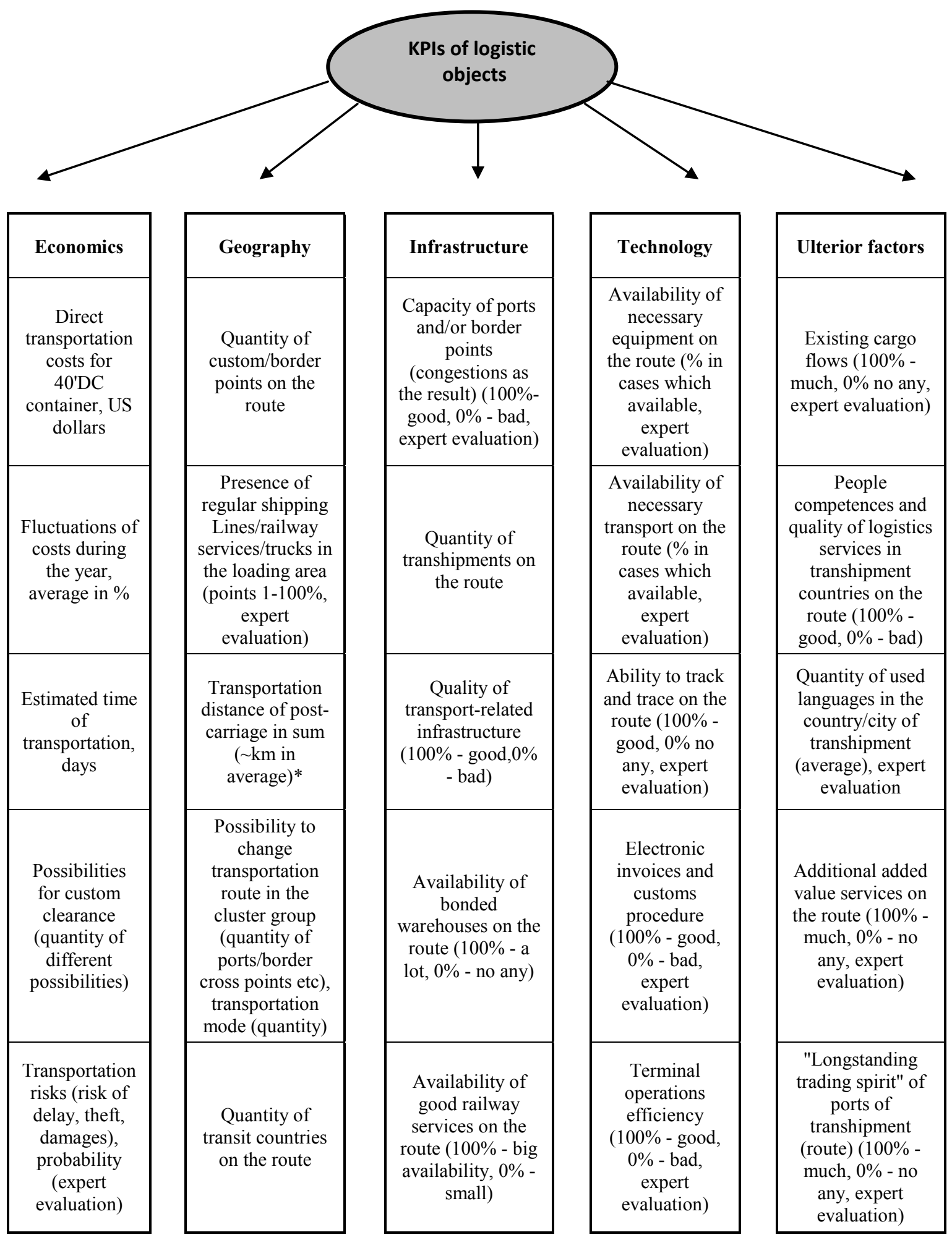

Figure 3. The Taxonomy of the set of key performance indicators Kvi and their quantitative metrics

After the initial steps of the decision making process (defining the alternative transportation actions and establishing the appropriate performance criteria) are realized the relative weight to each performance criterion to reflect its importance compared to other criteria may be defined. The known methods can be used to establish such weights: equal weighting, direct weighting, regression-based 
observer-derived weighting, the Delphi approach, the gamble method, pair wise comparison by the analytical hierarchy process and value swinging (Sinha, 2007).

The Authors chose the pair wise comparison by the analytical hierarchy process because this is method based on qualitative measurements and we have a lot of such measurements in the Research. Therefore the results are translated into numerical form which is very essential in terms of this Research.

\section{Establishment of relative importance of performance criteria}

The relative importance of performance criteria based on Experts Decisions was established accordingly to AHP (Analytic Hierarchy Process) method (Saaty, 2001). The companies and the real cargos' owners (located in Russia) that trade with China on a regular basis were put in the role of experts:

1. Equipment and machinery Trader;

2. Textile Trader;

3. Metal Company;

4. Chemical Trader;

5. Conserved Food Importer;

6. Shoes Manufactory;

7. Cars Importer.

This choice of Decision Makers was performed accordingly to the Statistics of Import from China to Russia for year 2012 and main "groups" of cargo:

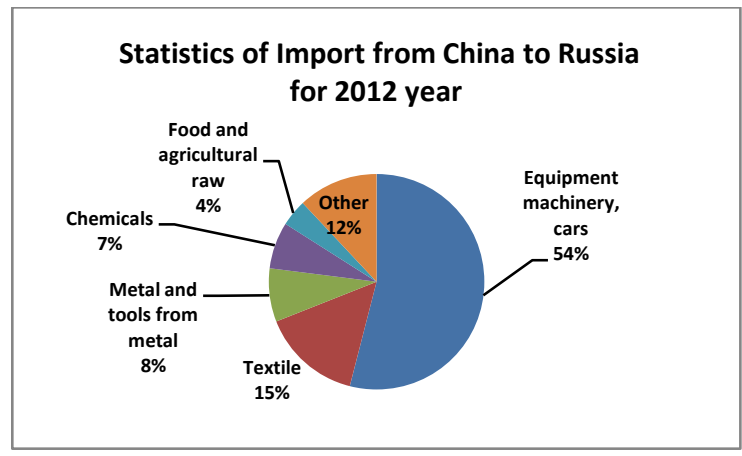

Figure 4. Statistics of Import from China to Russia

The AHP (Analytic Hierarchy Process) is based on paired comparison and seems to be the best choice in this context since it allows structuring the choice procedure as a hierarchy of several levels (Saaty, 2001). This method allows to evaluate the significance of each factor and to find the best alternative according to experts' decisions at the first stage of evaluation.

Table 1. Paired comparisons matrix for criteria (first hierarchy level)

\begin{tabular}{|c|c|c|c|c|c|c|}
\hline Criteria & 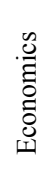 & 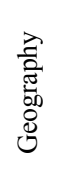 & 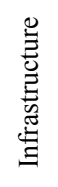 & 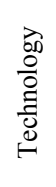 & 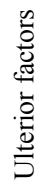 & Priority vector \\
\hline Economics & 1 & 1 & 5 & 7 & 7 & 0.4116 \\
\hline Geography & 1 & 1 & 3 & 5 & 7 & 0.3474 \\
\hline Infrastructure & $1 / 5$ & $1 / 3$ & 1 & 3 & 5 & 0.1369 \\
\hline Technology & $1 / 7$ & $1 / 5$ & $1 / 3$ & 1 & 3 & 0.0672 \\
\hline Ulterior factors & $1 / 7$ & $1 / 7$ & $1 / 5$ & $1 / 3$ & 1 & 0.0365 \\
\hline
\end{tabular}

Conformity Relation =

$3.78 \%$

The relative importance of KPIs based on Experts Decisions was established accordingly to AHP (Analytic Hierarchy Process) method and the most decisive KPI is "Economics" with the priority vector 0.4116. 


\section{Establishment of commensurate scale for measuring importance levels of each criteria}

Each of the five key performance indicators $\mathrm{K}_{\mathrm{vi}}$ has five set of parameters $\mathrm{P}_{\mathrm{aj}}$. The relative importance of parameters was determined at the 2 nd stage. There are five calculations in total. The paired comparison matrix for criteria "Economics" and its parameters is presented in the Table 2.

Table 2. Paired comparison matrix for criteria (2nd hierarchy level)

\begin{tabular}{|c|c|c|c|c|c|c|}
\hline Criteria & 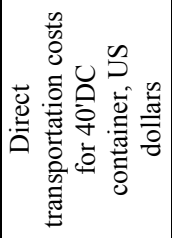 & 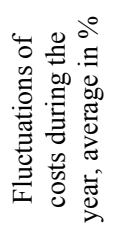 & 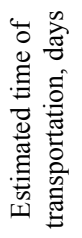 & 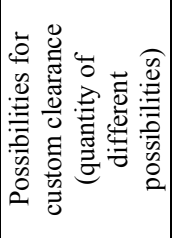 & 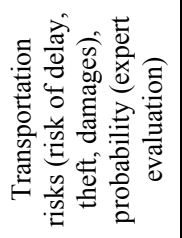 & $\begin{array}{l}\text { Priority } \\
\text { vector }\end{array}$ \\
\hline $\begin{array}{l}\text { Direct transportation costs for } \\
40^{\prime} \mathrm{DC} \text { container, US dollars }\end{array}$ & 1 & 7 & 2 & 3 & 6 & 0.4460 \\
\hline $\begin{array}{c}\text { Fluctuations of costs during the } \\
\text { year, average in } \%\end{array}$ & $1 / 7$ & 1 & $1 / 5$ & $1 / 7$ & $1 / 2$ & 0.0428 \\
\hline $\begin{array}{l}\text { Estimated time of transportation, } \\
\text { days }\end{array}$ & $1 / 2$ & 5 & 1 & 2 & 3 & 0.2537 \\
\hline $\begin{array}{l}\text { Possibilities for custom clearance } \\
\text { (quantity of different possibilities) }\end{array}$ & $1 / 3$ & 7 & $1 / 2$ & 1 & 2 & 0.1748 \\
\hline $\begin{array}{l}\text { Transportation risks (risk of delay, } \\
\text { theft, damages), probability } \\
\text { (expert evaluation) }\end{array}$ & $1 / 6$ & 2 & $1 / 3$ & $1 / 2$ & 1 & 0.0828 \\
\hline
\end{tabular}

Conformity Relation $=$

$2.58 \%$

The relative importance of parameters based on Experts Decisions was established accordingly to AHP (Analytic Hierarchy Process) method and the most decisive parameter in the group of "Economics" is "Direct transportation costs for 40 'DC container, US dollars" with the priority vector 0.4460 .

\section{Quantifying the impact of each parameter for each alternative}

Using the expert evaluation process the impact of each of twenty-five parameters was determined for each alternative. In the example below the previous most decisive parameter in the group of Economics is illustrated.

Table 3. Priority vector determination of the parameter "Direct transportation costs for 40'DC container, US dollars"

\begin{tabular}{|c|c|c|c|c|c|c|c|c|c|}
\hline & 离 & 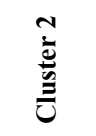 & 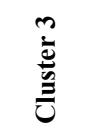 & 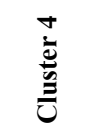 & 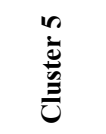 & $\begin{array}{l}0 \\
\vdots \\
\vdots \\
\vdots \\
0 \\
0\end{array}$ & 苞 & $\begin{array}{l}\text { Priority } \\
\text { vector }\end{array}$ & $\begin{array}{c}\text { Priority } \\
\text { vector } \\
\text { (normalized) }\end{array}$ \\
\hline Cluster 1 & 1 & 1 & $1 / 3$ & 2 & 7 & 6 & 8 & 2.1665 & 0.2038 \\
\hline Cluster 2 & 1 & 1 & $1 / 3$ & 2 & 7 & 6 & 8 & 2.1665 & 0.2038 \\
\hline Cluster 3 & 3 & 3 & 1 & 3 & 7 & 6 & 9 & 3.7385 & 0.3517 \\
\hline Cluster 4 & $1 / 2$ & $1 / 2$ & $1 / 3$ & 1 & 5 & 4 & 7 & 1.4204 & 0.1336 \\
\hline Cluster 5 & $1 / 7$ & $1 / 7$ & $1 / 7$ & $1 / 5$ & 1 & $1 / 2$ & 6 & 0.4038 & 0.0380 \\
\hline Cluster 6 & $1 / 6$ & $1 / 6$ & $1 / 6$ & $1 / 4$ & 2 & 1 & 7 & 0.5549 & 0.0522 \\
\hline Cluster 7 & $1 / 8$ & $1 / 8$ & $1 / 9$ & $1 / 7$ & $1 / 6$ & $1 / 7$ & 1 & 0.1791 & 0.0168 \\
\hline SUM & 5.9345 & 5.9345 & 2.4206 & 8.5929 & 29.1667 & 23.6429 & 46.0000 & 10.6296 & 1.0000 \\
\hline
\end{tabular}

Conformity relation

$6.77 \%$ 
Quantifying the impact of each parameter for each alternative we could compare the normalized priority vectors and conclude that the higher vector of importance belongs to the alternative number 3 (Cluster 3). This is "Transportation through St. Petersburg port, Ust Luga port".

\section{Establishment of the combined impact of the different criteria for each alternative}

Using previous information we find the priorities in the group of KPI (economics, infrastructural, technologic, geographical and ulterior factors). The priorities in the group "Economics" are presenter in the Table 4.

Table 4. The combined impact of the different criteria (in the group "Economics") for each alternative

\begin{tabular}{|l|c|c|c|c|c|c|}
\hline \multirow{2}{*}{ Alternatives } & \multicolumn{4}{|c|}{ Criteria (ECONOMICS) } \\
\cline { 2 - 7 } & $\begin{array}{c}\text { Direct } \\
\text { transportation } \\
\text { costs for } \\
\text { 40'DC } \\
\text { container, US } \\
\text { dollars }\end{array}$ & $\begin{array}{c}\text { Fluctuations } \\
\text { of costs } \\
\text { during the } \\
\text { year, } \\
\text { average in \% }\end{array}$ & \begin{tabular}{c} 
Estimated time \\
of \\
transportation, \\
days \\
\cline { 2 - 7 }
\end{tabular} & $\begin{array}{c}\text { Possibilities } \\
\text { for custom } \\
\text { clearance } \\
\text { (quantity of } \\
\text { different } \\
\text { possibilities) }\end{array}$ & $\begin{array}{c}\text { Transportation } \\
\text { risks (risk of } \\
\text { delay, theft, } \\
\text { damages) } \\
\text { probability } \\
\text { (expert } \\
\text { evaluation) }\end{array}$ \\
\hline Cluster 1 & 0.445970 & 0.042755 & 0.253655 & 0.174832 & 0.082789 \\
\hline Cluster 2 & 0.203814 & 0.020835 & 0.032985 & 0.053502 & 0.051612 \\
\hline Cluster 3 & 0.203814 & 0.032638 & 0.032985 & 0.053502 & 0.051612 & 0.1137 \\
\hline Cluster 4 & 0.351705 & 0.052171 & 0.041896 & 0.259115 & 0.051612 & 0.2192 \\
\hline Cluster 5 & 0.133630 & 0.072491 & 0.064346 & 0.071764 & 0.126793 & 0.1020 \\
\hline Cluster 6 & 0.037985 & 0.159713 & 0.283719 & 0.259115 & 0.204555 & 0.1579 \\
\hline Cluster 7 & 0.052205 & 0.285831 & 0.345484 & 0.259115 & 0.275310 & 0.0560 \\
\hline
\end{tabular}

The combined impact of the different criteria for each alternative was established.

\section{Determination of the most satisfying alternative}

Using previous information the most satisfying alternatives between seven clusters was determined. Matrix of evaluations of the vector of the criteria priorities is shows in the Table 5.

Table 5. Determination of the most satisfying alternative

\begin{tabular}{|c|c|c|c|c|c|c|}
\hline \multirow{4}{*}{ Alternatives } & \multicolumn{5}{|c|}{ Criteria } & \multirow{4}{*}{$\begin{array}{c}\text { Priorities in } \\
\text { the group }\end{array}$} \\
\hline & Economics & Geography & Infrastructure & Technology & $\begin{array}{l}\text { Ulterior } \\
\text { factors }\end{array}$ & \\
\hline & \multicolumn{5}{|c|}{ Priority vector } & \\
\hline & 0.411650 & 0.347482 & 0.136992 & 0.067279 & 0.036596 & \\
\hline Cluster 1 & 0.113779 & 0.065736 & 0.197719 & 0.202189 & 0.231672 & 0.1188 \\
\hline Cluster 2 & 0.114284 & 0.057042 & 0.192963 & 0.228496 & 0.197814 & 0.1159 \\
\hline Cluster 3 & 0.219282 & 0.190588 & 0.148336 & 0.208958 & 0.116202 & 0.1951 \\
\hline Cluster 4 & 0.102060 & 0.148337 & 0.103029 & 0.169197 & 0.137684 & 0.1240 \\
\hline Cluster 5 & 0.157971 & 0.180409 & 0.132036 & 0.101610 & 0.204844 & 0.1601 \\
\hline Cluster 6 & 0.056064 & 0.145958 & 0.112073 & 0.070190 & 0.109594 & 0.0777 \\
\hline Cluster 7 & 0.036924 & 0.040032 & 0.057079 & 0.058955 & 0.034289 & 0.0377 \\
\hline
\end{tabular}

The most satisfying alternatives between seven clusters are:

1. Cluster 3 - Transportation through St. Petersburg port, Ust Luga port (priority - 0.1951);

2. Cluster 5 - Transportation through Vladivostok, Nahodka, Vostochny ports - Russian East ports (priority - 0.1601);

3. Cluster 4 - Transportation through Novorossiysk, Odessa ports (priority - 0.1240). 


\section{Resume}

A shift of economic mass to emerging economies has been seen in recent years. As a result, supply chain configurations are becoming increasingly volatile and the shift in the global economic centre of gravity to emerging regions may see reduced growth on traditional trade routes. According to the (McKinsey Global Institute, 2012) the economic centre of gravity has been shifting east for the past decade at the rate of $140 \mathrm{~km}$. Reconfiguring supply chains around customers has led to the necessity for more flexible and adaptive formation system of transport and logistics links. In this situation decision support system (DSS) is one of the instruments for choosing the most effective decision for customer in constant fluctuated business environment.

Global container cargo flows strongly depend on large commercial markets like Asia and Europe. Meanwhile China currently is one of key exporters of containerized cargoes in the world. The flows of containerized cargoes in the Easter Baltic ports region are determined by the neighbourhood of consumer markets with Russia being the key destination point of such cargoes.

The multi-criteria decision making process of route choice for containerized cargo flows coming from China with destination points in Russia via Baltic Sea Region is a/the case study of DSS development for the large scale transportation transit system.

There are a lot of major issues in business decision making in the international container transportation industry and cargo owners determine the mode by which they will have their freight transported, considering mainly their corporate, personal priorities. Firstly - the lack of systemized information with respect to the criteria for decision making.

From another side the standard System of KPI of ports and other Logistics objects currently used in the Baltic States came down to the very simple providing an incomplete picture of competitiveness.

That's why the set of key performance indicators $\mathrm{K}_{\mathrm{vi}}$ and set of parameters $\mathrm{P}_{\mathrm{aj}}$ of should be determined to suggest further the multiple-criteria approach for evaluation and the alternatives of cargo transportation in the large scale transportation transit system with special attention to the Baltic Sea Region.

Therefore the multiple-criteria approach for the evaluation and choosing the alternatives of cargo transportation in the large scale transportation transit system with special attention to the Baltic Sea Region was suggested. The multimodal transportation system with finite number of known alternatives defined by the routes and modes of transportation was considered. Each alternative was represented by its performance in multiple criteria.

The large scale transportation transit system was presented by directed finite graph which is an ordered pair $\mathrm{D}=(\mathrm{V}, \mathrm{A})$ where $\mathrm{V}$ is a set of finite vertices (railway stations, ports, border points and logistics centres) and $\mathrm{A}$ is set of finite arcs (transport lines between ports and/or logistics centres).

Each vertex $\mathrm{Vi}(\mathrm{V}=\{\mathrm{Vi}\}, \mathrm{i}=1, \ldots \mathrm{n})$ was characterized by an individual set of key performance indicators $\mathrm{K}_{\mathrm{vi}}$ and each arc aj $(\mathrm{A}=\{\mathrm{aj}\}, \mathrm{j}=1, \ldots \mathrm{m})$ was characterized by an individual set of parameters $\mathrm{P}_{\mathrm{aj}}$.

There could be found several alternatives for cargo delivery determined by different routes and modes which form the vector space of a family of alternative transit vector routes. The 57 alternatives for cargo delivery based on case study were described. All 57 alternatives were classified to 7 clusters. The multiple-criteria approach was suggested. A two-level hierarchy system of criteria with ranging expert evaluations based on Analytic Hierarchy Process Method was developed. The best alternatives were suggested according to this method.

The multiple-criteria approach for evaluation and choice the alternatives of cargo transportation in the large scale transportation transit system for the decision makers - cargo owners was suggested in this Paper. In further researches more complete model for decision of the route choice will be described, with special emphasis on BSR; the criteria of optimization will be formulated.

\section{References}

1. Kopytov, E., Abramov, D. (2010). Modelling of multimodal freight transportation system using process approach. In: Proceedings of the 13th International Conference on Harbour Maritime Multimodal Logistics Modelling and Simulation, Rome, Italy, September 12-14, 2011, pp. 46-51.

2. Midoro, R., Musso, E. and Parola, F. (2005) Maritime liner shipping and the stevedoring industry: market structure and competition strategies. In: Maritime Policy and Management, 32(2), pp. 95106.

3. Containerised Cargo Shipments: "China-Baltic States" Trade Line: Mikulko J. (2013). Journal: "Economics and Management", ISSN: 1822-6515. 
4. The World Bank (2013), Review of the ports sector of Latvia: Competitiveness and governance, October issue.

5. Alminas Maciulis, Aidas Vasilis Vasiliauskas, Grazvydas Jakubauskas (2009). The Impact of the Competitiveness of National Economy. "Transport”, 24(2), pp. 93-99.

6. Igor Kabashkin (2003). The Problems of Transport and Logistics in European Research Area. In: Proceedings of the International Conference "logistics and Transport in International Trade", 3-4 December 2003, pp. 18-32.

7. McKinsey Global Institute (2012). Urban world: Cities and the rise of the consuming class. Report from June 2012.

8. Kumares C.Sinha, Samuel Labi (2007). Transportation Decision Making. Principles of Project Evaluation and Programming. John Wile \& Sons, Inc.

9. Saaty, T. L. (2001). Decision Making for Leaders: The Analytic Hierarchy Process for Decisions in A Complex World. Pittsburgh, PA: RWS Publications. 